\title{
STUDYING THE INFLUENCE OF PLASMA-CHEMICAL AND OZONE TREATMENT ON ARTIFICIALLY IMPLEMENTED MICROFLORA IN MODEL AQUEOUS SOLUTIONS
}

\author{
G.V. Taran ${ }^{1}$, D.V. Kudin', O.O. Zamuriev', P.O. Opalev ${ }^{1}$, M.O. Yaroshenko', \\ O.M. Korneikov, ${ }^{2}$ V.L. Arefiev', M.V. Kalashnik ${ }^{2}$ \\ ${ }^{1}$ National Science Center “Kharkov Institute of Physics and Technology”, Kharkiv, Ukraine; \\ ${ }^{2}$ National Science Center "Institute of Experimental and Clinical Veterinary Medicine”, \\ Kharkiv, Ukraine \\ E-mail: kudin@kipt.kharkov.ua
}

The pilot studies have been conducted to determine the biocidal effects of ozone and plasma chemical treatment for 1,2 , and $3 \mathrm{~h}$ on the strain "Moldavian" of infectious rhinotracheitis virus, reference strain of Escherichia coli ATCC 25922, atypical mycobacteria of the species Mycobacusleum phlei and archival strain of Aspergillus flavus artificially introduced into aqueous solution. It is shown that both treatments of aqueous solution contaminated with infectious rhinotracheitis virus have virucidal properties at the level of $95 \ldots 100 \%$. It was found that bactericidal (bacteriostatic) effect of ozone treatment for Escherichia coli fluid was $100 \%$ for all the time parameters. For plasma chemical treatment, the bacteriostatic effect $(23 \%)$ was shown after the treatment within $3 \mathrm{~h}$. The bactericidal (bacteriostatic) effect of ozone treatment for water samples contaminated with mycobacteria of the species M. phlei was only $65 \%$ at the treatment for $3 \mathrm{~h}$. There was no bacteriostatic effect for plasma chemical treatment at any exposure. When studying the fungicidal (fungistatic) properties of ozone treatment for aqueous solution contaminated with a test culture of Aspergillus flavus, fungicidal properties were established (growth retardation by $95 . . .98 \%$ ). No fungicidal or fungistatic properties were shown for plasma chemical treatment.

PACS: 52.80. Hc, 52.90.+z,52.75.-d

\section{INTRODUCTION}

The issue of clean water closely depends on the assessment of the microbiological spectrum for surface water used in water treatment systems. Species composition and quantity of microorganisms in drinking water are the most important indicators of its quality. Water contaminated with bacteria, viruses, micromycetes may cause irreparable consequences for life and health of animals and humans. Natural water may contain a large number of different pathogens. Therefore, the issue of non-harmful disinfection of water, i.e. using the methods that do not pose any danger to living organisms, is timely and relevant [1].

Nowadays, alternative methods of water disinfection (e.g., ozone treatment) become increasingly important. This can significantly improve the quality of drinking water and solve many issues that arise when using traditional methods (e.g., chlorination). It is known that more than 1000 water supply stations in Europe (France, Germany, and Switzerland) use ozone treatment as a part of the overall process. Recently, ozone treatment has been used in Japan, USA, and CIS countries (Moscow, Kiev, Minsk, etc.) [2].

Due to high oxidative potential, ozone interacts with many organic minerals, including the protoplasm of bacterial cells, destroying them [3]. The biocidal action of ozone is the result of its reaction with fatty acids in a double bond in the cell walls and membranes of bacteria, in the protein shells of viruses. In case of bacteria, oxidation leads to the changes in cell permeability and the transition of cell contents into solution. For viruses, the change in the protein shell prevents them from being captured by susceptible cells.
Ozone has a strong bactericidal, virucidal, sporicidal and fungicidal action [4, 5]. In particular, the greatest sensitivity to ozone was observed in both indicator bacteria and pathogens. But, at the same time, the sensitivity of viruses and protozoa to ozone is much lower. Doses of residual ozone required for water disinfection at different levels of its contamination, such as enteroviruses (duration of contact $12 \mathrm{~min}$ ) are the following: at $5 \ldots .50 \mathrm{IU} / \mathrm{dm}^{3}-0.2 \ldots 0.3 \mathrm{mg} / \mathrm{dm}^{3}$; at $400 \rightarrow 0.5$ and at $4000 \ldots 30000 \rightarrow 0.8$. The parameters of effective modes depend on the quality of water, technology used, structure of water treatment plant at specific sites, and in each case should be specified [6 - 9].

However, for all its advantages, the ozone treatment method has a number of disadvantages. Ozone is not active enough in the destruction of phenolic compounds. During ozone treatment, carcinogenic formaldehyde is produced, the amount of which should be controlled. Ozone belongs to the high hazard class of substances, so it should be used in compliance with all the technological rules [10].

Therefore, the search for new methods of water purification to reduce the disadvantages of ozone treatment, which could replace or supplement the existing methods, is an urgent task, especially with the pandemic caused by the virus COVID-19 in the background.

\section{MATERIALS AND METHODS}

In connection with the abovementioned and in order to study the biocidal effect of ozone and plasma chemical (PH) treatment, the pilot studies were conducted on the treatment of water with artificially introduced test cultures: infectious bovine rhinotracheitis (IBR) of the strain "Moldavian", Escherichia coli ATCC 
25922, atypical mycobacteria of the species M. phlei and museum strain Aspergillus flavus (A.X.5).

The research was conducted on two specially designed and manufactured experimental stands for ozone and plasma chemical treatment of solutions. On the experimental stand for ozone treatment of solutions, ozone synthesis was carried out in laboratory air using the barrierless ozone generator. Then the resulting ozone-air mixture was bubbled through the solution. On the experimental stand for plasma chemical treatment of solutions, the gas discharge was ignited directly above the surface of the solution, i.e. the solution was the anode.

The first stand (Fig. 1) included the following functional units: Secoh sangyo air compressor (Japan) with the capacity of $50 \mathrm{l} / \mathrm{min}$ and the maximum pressure of up to $12.7 \mathrm{kPa}$, gas flow meter (PM-4 GU3), "StreamOzone" ozone generator, Teledyne instruments (USA) $454 \mathrm{H}$ ozone monitor with the range of ozone concentration measurement of $0.1 \ldots 100 \mathrm{~g} / \mathrm{m}^{3}$, laboratory mattress to accommodate samples of the test solution and ozone destructor. The volume of solution in the bubbling container was 21 . Ozone concentration in the ozone-air mixture was $5 \mathrm{~g} / \mathrm{m}^{3}$ at the flow rate of $8 \mathrm{l} / \mathrm{min}$.

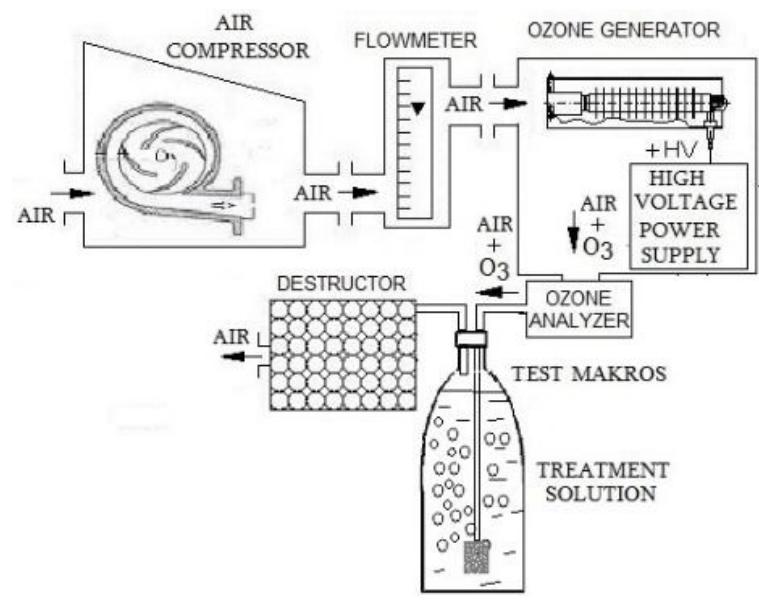

Fig. 1. The system for ozone treatment of the solution under study

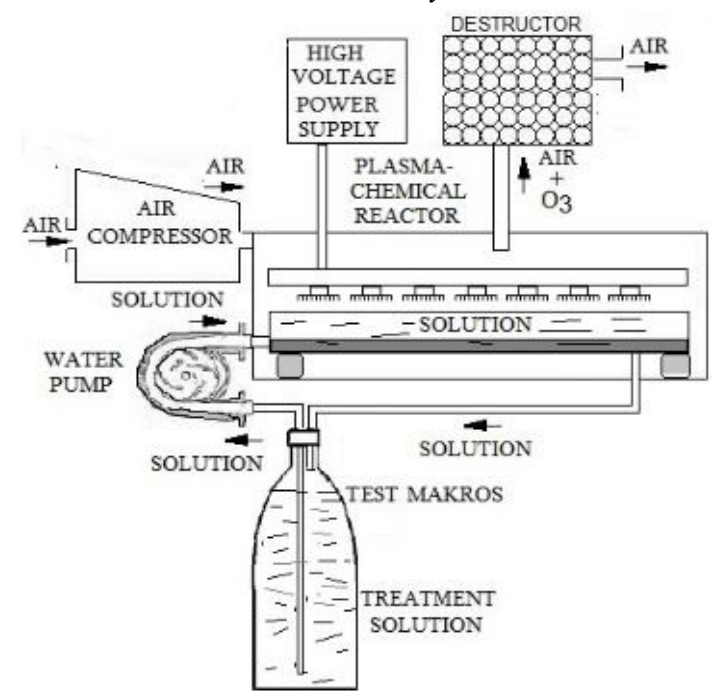

Fig. 2. The system for plasma chemical treatment of solutions

The second experimental stand (Fig. 2) included: a specially designed plasma chemical reactor for discharge formation with one liquid electrode, HV pulsed power supply with the maximum capacity of $150 \mathrm{~W} \cdot \mathrm{h}$, $1000-Z B$ water pump with the capacity of $60 \mathrm{l} / \mathrm{h}$, SunSun ACO-003 air compressor with the capacity of $38 \mathrm{1} / \mathrm{min}$ to generate air flow through the discharge gap, flattened bottle for the samples of the test solution, and destructor. The HV pulsed power supply generates highvoltage pulses of microsecond duration (1300 ns) with the pulse repetition rate of $1 \ldots 15 \mathrm{kHz}$ and the amplitude of up to $12 \mathrm{kV}$. The pulse rise time is $500 \mathrm{~ns}$. The volume of solution in the system was 41 .

To correctly compare the experimental results on the biocidal effect of these treatment methods, the parameter of the same input power per unit volume of the solution at the level of $20 \mathrm{~W} / \mathrm{l}$ was selected and kept constant throughout the experiment.

Determination of biocidal properties was performed by bubbling ozone through the aqueous solution and using high-voltage discharge on the liquid surface. The volume of the solution was 2 and $4 \mathrm{dm}^{3}$, respectively, with a certain working dilution of each test culture. The study was performed at room temperature $(18.5 \pm 0.5)^{\circ} \mathrm{C}$ with exposure for 1,2 , and $3 \mathrm{~h}$.

When determining the virucidal effect of ozone and plasma chemical treatment on viral infection, the adaptation and restoration of biological properties for the transplanted calf kidney culture (NT) was carried out as well as the restoration of infectious activity for IBR (IRT cattle, BHV-1) of the strain "Moldavian" after a long-term storage at $-70^{\circ} \mathrm{C}$. Standardization of the IBR viral suspension (made on saline) was performed in accordance with the infectious activity of the virus.

After each time range, aliquots $\left(2.0 \mathrm{~cm}^{3}\right)$ were taken, the treated virus-containing mixture was applied to the cell culture monolayer and co-incubated at $(37.0 \pm 0.5)^{\circ} \mathrm{C}$ for $60 \mathrm{~min}$. Then, the virus-containing mixture was removed from the cell culture monolayer, the growth medium $\left(2.0 \mathrm{~cm}^{3}\right)$ was added, and the samples were incubated at $(37.0 \pm 0.5)^{\circ} \mathrm{C}$ until the characteristic cytopathic changes occurred in the control samples. Determination of the effectiveness for different treatment variants of virus-containing mixture was performed by evaluating the development of virus-induced cytopathic effect (CPE) on sensitive cell culture. The results of the study were analyzed in accordance with the results of $100 \% \mathrm{CPE}$ of the virus in monolayer cells of the control samples. The monolayer state, its integrity, changes in cell morphology for the appropriate controls and test tubes containing different variants and exposures of pathogen treatment were taken into account [11 - 17].

Determination of bactericidal (bacteriostatic) properties of ozone and plasma chemical treatment was studied using the reference strain of Escherichia coli ATCC 25922 , which was stored at low temperature $\left(-70^{\circ} \mathrm{C}\right)$. To prepare the test sample from cryopreserved bacteria, the working inoculum of Escherichia coli ATCC 25922 was prepared with the concentration of $1.0 \times 10^{8}$ colonyforming units/ml by successive inoculations on nutrient media. The results were analyzed using parallel bacterial inoculation of inoculum samples exposed to ozone and plasma chemical discharge at the abovementioned time parameters. The bacterial inoculum sample taken 
prior to the experiment and stored unchanged was used as the control sample.

The research to determine the bactericidal properties of ozone and plasma chemical treatment against atypical mycobacteria of the species Mycobacterium phlei was conducted using a five-day bacterial mass of $\mathrm{M}$. phlei living culture at the concentration of 200 million $/ \mathrm{cm}^{3}$. The experimental and control samples of water from each individual flattened bottle taken after the treatment were studied by the culture method for the presence of viable colonies of M. phlei [18].

Research on the study of fungicidal (fungistatic) effects of ozone and plasma chemical treatment on the test culture of Aspergillus flavus, previously introduced into aqueous solutions (working dilution $\approx 120$ spores in $1 / 5 \mathrm{~mm}^{2}$ ), was conducted in accordance with generally accepted and developed laboratory methods [19 - 21]. To count the number of spores that survived after the treatment, $3.0 \mathrm{~cm}^{3}$ of micromycete-contaminated solution was inoculated in labeled Petri dishes with Chapek agar medium and incubated at $25 \ldots 27^{\circ} \mathrm{C}$ at the abovementioned time. The colony counts were performed on days 3,5 , and 7 . After the cultivation, in the abovementioned terms, a macroscopic study of the cultures and comparison with the colonies of museum strains were carried out. The experimental parameters, in which the death of spores for the test cultures was ensured by $95 \ldots 98 \%$ in the presence of their growth in the control sample, were considered to be effective [22].

\section{EXPERIMENTAL RESULTS}

When determining the virucidal action of ozone and plasma chemical treatment, the biological properties for the transplanted culture of calf kidney (CK) cells was first adapted and restored, and the activity of IBR virus in cattle (IBR, BHV-1) of the strain "Moldavian" was confirmed.

The infectious activity of IBR virus in HT cell culture was $\left(7.6 \lg\right.$ TCD $\left.50 / \mathrm{cm}^{3}\right)$. The specified indicator is defined as a start when studying the efficiency of the activator disinfection methods.

Determination of antiviral efficiency of ozone and plasma chemical treatment for the pathogen IBR in vitro was performed $20 \mathrm{~h}$ after the application of appropriate materials to the cell monolayer and infection with the virus; the changes in cell morphology and monolayer detachment at the level of $100 \%$ were observed in control samples (CS). During this time, the cell morphology and monolayer integrity for the control samples of NT cell culture remained unchanged (Table 1).

Analysis of the results for CPE development in $20 \mathrm{~h}$ after infection of $C K$ cell culture with IBR

Table 1

\begin{tabular}{|c|c|c|c|c|c|c|c|c|c|c|c|}
\hline \multirow{2}{*}{$\begin{array}{c}\text { № } \\
\text { Sample }\end{array}$} & \multirow{2}{*}{$\mathrm{CC}$} & \multirow{2}{*}{$\mathrm{CS}$} & \multirow{2}{*}{$\begin{array}{l}\text { CS } \\
1 \mathrm{~h}\end{array}$} & \multirow{2}{*}{$\begin{array}{l}\mathrm{CS} \\
2 \mathrm{~h}\end{array}$} & \multirow{2}{*}{$\begin{array}{l}\mathrm{CS} \\
3 \mathrm{~h}\end{array}$} & \multicolumn{3}{|c|}{ Ozone } & \multicolumn{3}{|c|}{ PCR } \\
\hline & & & & & & $1 \mathrm{~h}$ & $2 \mathrm{~h}$ & $3 \mathrm{~h}$ & $1 \mathrm{~h}$ & $2 \mathrm{~h}$ & $3 \mathrm{~h}$ \\
\hline 1 & - & ++++ & ++++ & ++++ & +++ & - & - & - & - & - & - \\
\hline 2 & - & ++++ & ++++ & ++++ & +++ & - & \pm & - & - & - & - \\
\hline 3 & - & ++++ & ++++ & ++++ & ++++ & - & - & + & - & \pm & - \\
\hline 4 & - & ++++ & ++++ & ++++ & ++++ & - & - & - & - & \pm & + \\
\hline 5 & - & ++++ & ++++ & ++++ & ++++ & - & - & - & \pm & - & - \\
\hline $\mathrm{M}$ & 0 & 100 & 100 & 100 & 90 & 0 & 1.00 & 5.00 & 1.00 & 2.00 & 5.00 \\
\hline $\mathrm{m}$ & 0 & 0 & 0 & 0 & 6.12 & 0 & 1.00 & 5.00 & 1.00 & 1.22 & 5.00 \\
\hline
\end{tabular}

Note: "—" no CPE of the virus; " \pm " - CPE of the virus is at the level of $5 \%$; "+" - CPE of the virus is at the level of $25 \%$; "++" - CPE of the virus is at the level of $50 \%$; "+++" - CPE of the virus is at the level of $75 \%$; " $++++"-\mathrm{CPE}$ of the virus is at the level of $100 \%$.

With regard to the control samples to determine the virus viability in saline under the conditions of storage for 1,2 , and $3 \mathrm{~h}$, as in case of infecting the monolayer cells with IBR, the damage to monolayer cells and their detachment from glass were observed at the level of $100 \%$. Some decrease in the reproduction intensity of the pathogen on NT cells was observed for some samples after the virus was added to saline and stored for $3 \mathrm{~h}$.

As for the samples of the virus-containing fluid treated with ozone for one hour, its introduction into the transplanted culture of NT cells did not cause any changes in cell morphology, death or exfoliation of the monolayer, which shows the absence of virus reproduction at the time of registration. Treatment of the viruscontaining fluid by the abovementioned method for 2 and $3 \mathrm{~h}$ with the following application of the obtained samples to the monolayer of NT cell culture resulted in the damage of monolayer cells for the individual samples at the level of 5 and $25 \%$, respectively. In general, under the conditions of using the specified mode of

sample treatment for 2 and $3 \mathrm{~h}$ and subsequent application of the samples to the monolayer, the average preservation of NT cells was $(99.0 \pm 1.0)$ and $(95.0 \pm 5.0) \%$, respectively.

As for studying the effect of plasma chemical treatment on the reproduction of IBR virus after its treatment in saline for 1,2 , and $3 \mathrm{~h}$, the results similar to those described above were obtained. Thus, plasma chemical treatment for 1 hour led to the inhibition of virus reproduction and preservation of the monolayer integrity for NT cell culture at the level of $(99.0 \pm 1.0) \%$. Discharge exposure of the virus-containing fluid for 2 , and $3 \mathrm{~h}$ resulted in a virostatic effect, which was characterized by the preservation of cell morphology and monolayer integrity at the level of $(98.0 \pm 1.22)$ and $(95.0 \pm 5.0) \%$, respectively. It should be noted that, as in case of ozone treatment, the damaged cells were observed for individual samples (1-2 of 5), which requires further study. In addition, the lack of direct correlation between the treatment time of the virus-containing fluid and the level 
of virus reproduction inhibition encourages further advanced research in this direction.

When determining the bactericidal (bacteriostatic) properties of ozone and plasma chemical treatment in relation to the reference strain Escherichia coli ATCC 25922 , it was found that ozone at all stages of exposure affected the growth of Escherichia coli: no growth was observed neither in liquid nor in solid culture media. In comparison with the control for liquid medium, a uniform turbidity was noted, which shows the presence of bacterial growth. As to the control for dense medium, a significant growth of small colonies was observed over the entire surface of the agar.

When studying the effect of plasma chemical treatment at the exposure for $1 \mathrm{~h}$, a dense uniform turbidity was observed on a liquid culture medium, and a significant bacterial growth was observed in a solid medium over the entire surface of the agar. After $2 \mathrm{~h}$ of exposure, a noticeable uniform turbidity of the liquid medium was observed, and the growth of single bacterial colonies was observed in a solid medium. After the exposure for $3 \mathrm{~h}$ no growth of bacteria was observed in either liquid or solid culture medium in comparison with the continuous growth in the control for both liquid and solid cuture medium.

When determining the bactericidal properties of ozone and plasma chemical treatment against mycobacteria of the species M. phlei, the results shown in Table 2 were obtained.

The results on the study of the bactericidal effect of ozone and plasma chemical treatment on $M$. phlei

\begin{tabular}{|c|c|c|c|c|c|c|c|c|c|}
\hline \multirow{2}{*}{ № } & \multirow{2}{*}{$\begin{array}{l}\text { Treatment } \\
\text { method }\end{array}$} & \multirow{2}{*}{$\begin{array}{c}\text { Exposition, } \\
\mathrm{h}\end{array}$} & \multicolumn{7}{|c|}{ The growth of mycobacteria colonies, days } \\
\hline & & & 1 & 2 & 4 & 5 & 12 & 19 & 26 \\
\hline \multirow{3}{*}{1} & \multirow{3}{*}{ Ozone } & 1 & - & - & +++ & ++++ & ++++ & ++++ & ++++ \\
\hline & & 2 & - & - & - & ++ & +++ & ++++ & ++++ \\
\hline & & 3 & - & - & - & + & ++ & ++ & ++ \\
\hline \multirow{3}{*}{2} & \multirow{3}{*}{$\begin{array}{l}\text { Plasma chemi- } \\
\text { cal discharge }\end{array}$} & 1 & - & - & +++ & +++ & +++ & ++++ & ++++ \\
\hline & & 2 & - & - & +++ & +++ & +++ & ++++ & ++++ \\
\hline & & 3 & - & - & - & ++ & +++ & ++++ & ++++ \\
\hline 3 & Control & 1 & - & + & ++++ & ++++ & ++++ & ++++ & ++++ \\
\hline
\end{tabular}

Notes: "-" - no growth; “+” - growth of $1 \ldots 10$ colonies; "++" - growth of $10 \ldots 20$ colonies; "+++" - growth of $20 \ldots 50$ colonies; " $++++"$ - more than 50 colonies

In accordance with the results (see Table 2) of ozone treatment of water samples contaminated with mycobacteria of the species M. phlei at the concentration of $200 \mathrm{million} / \mathrm{cm}^{3}$, the bactericidal effect of ozone was established only at the exposure of 3 hours.

No bactericidal or bacteriostatic action was found during the plasma chemical treatment of water samples contaminated with mycobacteria $\mathrm{M}$. phlei at the concentration of 200 million $/ \mathrm{cm}^{3}$ and exposures of 1, 2, and $3 \mathrm{~h}$.

When studying the fungicidal (fungistatic) properties of ozone and plasma chemical treatment of water contaminated with standardized by the number of spores test culture of Aspergillus flavus at the temperature of $(18.0 \pm 0.5)^{\circ} \mathrm{C}$ and exposure time of 1,2 , and $3 \mathrm{~h}$, the results presented in table 3 were obtained.

Table 3

The results of mycological studies of tap water, artificially contaminated with Aspergillus flavus, treated with ozone and plasma chemical discharge

\begin{tabular}{|l|c|c|c|c|c|c|}
\hline \multirow{2}{*}{ № of samples and exposure } & \multicolumn{5}{c|}{ Ozone treatment } & \multicolumn{2}{c|}{ PCR } \\
\cline { 2 - 6 } & \multicolumn{5}{|c|}{$\begin{array}{c}\text { Time period for calculating the growth } \\
\text { of colonies for A. flavus (days) }\end{array}$} \\
\cline { 2 - 7 } & 3 & 5 & 7 & 3 & 5 & 7 \\
\hline Sample № 1 - 1 h & - & $\mathbf{5}$ & $\mathbf{5}$ & + & + & + \\
\hline Sample № 2 - 2 h & - & $\mathbf{3}$ & $\mathbf{3}$ & + & + & + \\
\hline Sample № 3 - 3 h & - & $\mathbf{4}$ & $\mathbf{4}$ & + & + & + \\
\hline Positive control (untreated water with A. flavus culture) & + & + & + & + & + & + \\
\hline $\begin{array}{l}\text { Negative control (untreated water with A. flavus culture and } \\
\text { nystatin added to the nutrient medium (100 thousand IU per } \\
100.0 \mathrm{~cm}^{3} \text { of nutrient medium) }\end{array}$ & - & - & - & - & - & \\
\hline
\end{tabular}

In accordance with the results of Table 3, ozone treatment has fungicidal properties against the test culture of A. flavus; at the same time, exposure for 1, 2, and $3 \mathrm{~h}$ did not significantly affect the number of new colonies, which was 5, 3, and 4, respectively, in comparison with the continuous growth of A. flavus in the positive control and its absence in the negative.
When determining the fungicidal (fungistatic) action of plasma chemical treatment, it was found that this treatment did not affect the growth inhibition of the test culture in water. The continuous growth of A. flavus test culture was observed for all the experimental time exposures. 


\section{CONCLUSIONS}

1. Pilot studies were conducted to determine the biocidal effect of ozone and plasma chemical treatment on IBR virus of the strain "Moldavian", reference strain of Escherichia coli ATCC 25922, atypical mycobacteria of the species Mycobacterium phlei and museum strain of Aspergillus flavus artificially introduced into the water.

2. It was found that both treatments of aqueous solution contaminated with IBR virus of the strain "Moldavian" had virucidal properties at the level of $95 \ldots 100 \%$, regardless of the treatment time.

3. Studies on the bactericidal (bacteriostatic) efficiency of ozone treatment for the aqueous solution contaminated with the reference strain of Escherichia coli ATCC 25922 show $100 \%$ bactericidal action for all the time parameters. For plasma-chemical discharge, the bacteriostatic action $(23 \%)$ is shown at 3 -hour treatment.

4. Studies on the bactericidal (bacteriostatic) efficiency of ozone treatment for water samples contaminated with mycobacteria of the species M. phlei, show bacteriostatic properties by $65 \%$ only at the treatment for 3 hours. Plasma chemical treatment show no bacteriostatic effect at any time of treatment used in this experiment.

5. When studying the fungicidal (fungistatic) properties of ozone treatment for the aqueous solution contaminated with the test culture of Aspergillus flavus, it was found that ozone had fungicidal properties against the test culture of Aspergillus flavus: the growth inhibition by $95 \ldots 98 \%$ was observed. Plasmochemical discharge had neither fungicidal nor fungistatic properties; the continuous growth of Aspergillus flavus was shown at all the experimental parameters.

6 . The obtained preliminary results show a significant effectiveness of both methods on viruses and bacteria. However, the effect of plasma chemical treatment requires further research. The combined action of ozone and plasma chemical treatment of water to achieve a biocidal effect and reduce treatment time seems promising.

\section{REFERENCES}

1. L.F. Dolina. New methods and equipment for disinfection of wastewater and natural waters. Dnepropetrovsk: "Continent", 2003, $218 \mathrm{p}$.

2. V.V. Goncharuk, N.G. Potapchenko. The current state of the problem of water disinfection // Water chemistry and technology. 1998, v. 20, № 2, p. 190213.

3. G.V. Taran, V.A. Breslavets, A,A. Zamuriev, M.O. Yaroshenko, P.O. Opalev, O.V. Maiboroda. Plasma-chemical methods for control of biotic contaminants // Problems of Atomic Science and Technology. Series "Plasma Electronics and New Methods of Acceleration”. 2019, № 4, p. 198-202.

4. V.I. Golota, G.V. Taran, A.A. Zamuriev, et al. The use of ozone technologies in grain storage // Problems of Atomic Science and Technology. 2018, № 4(116), p. 185-188.

5. G.V. Taran, S.G. Pugach, A.A. Zamuriev, P.O. Opalev, M.O. Yaroshenko. Plasma-chemical method of grain fungal contamination control //
Problems of Atomic Science and Technology. 2020, № 6 (130), p. 127-130.

6. A. Poisson, A.V Chepurnov, V.P. Shchipetilnikov. "Ozonia" ozone generators of the fourth generation // Water supply and plumbing. 2000, № 1, p. 29-32.

7. D.A. Reckhow, P.C. Singer. Chlorination By products in drinking water from formation potentials to finished water concentrations // J. $A W W A$. 1990, issue 82, № 4, p. 173-180.

8. G. Hageskal, A.K. Knutsen, P. Gaustad, et al. // Appl. Environ. Microbiol. 2006, issue 72, № 12, p. 7586-7593.

9. M.S. Dogget // Ibid. 2000, issue 66, № 3, p. 12491257.

10. O.V. Mosin. The use of ozone in water treatment // Plumbing, heating, air conditioning. 2011, № 9(117), p. 40-43.

11.DSTU 4483:2005. Veterinary immunobiological preparations. Methods for determining bacterial and fungal contamination. Derzhspozhyvstandart of Ukraine. Kiev. 2006

12. S.N. Vishelessky. Guidelines for the study of cultural, antigenic, genetic properties and infectious activity of production and epizootic strains of bovine coronavirus. Institute of Experimental Veterinary named after. 2016, 22 p.

13. B.T. Stegniy, A.P. Gerilovich, O.Yu. Limanskaya, et al. Polymerase chain reaction in the practice of veterinary medicine and biological research. Scientific and methodical manual. Kharkiv, 2010, 227 p.

14. Determination of virucidal action for disinfectants. Guidelines. Order of the Ministry of Health of Ukraine. 08.04.2009, № 231.

15. Guidance for Industry Antiviral Product Development - Conducting and Submitting Virology Studies to the Agency. Center for Drug Evaluation and Research (CDER). https://www.fda.gov/media /71223/download.

16. V.N. Surin, B.N. Belousova, N.V. Fomina. Veterinary virology. M.: "Kolos", 1984, 376 p.

17. O.B. Shemendyuk, L.G. Zholner, N.M. Zholobak, M.Ya. Spivak // Antiviral and interferon-inducing action of aminoethocidiphenyls. Science news of NTUU “KPI”. 2015, № 3, p. 84-90.

18. Guidelines on the diagnosis of tuberculosis in animals and poultry, SOP T-13B-2015 Conducting a cultural study of biological material for tuberculosis. DSTU ISO / IEC 17025.

19. S.M. Semenov. Laboratory media for actinomycetes and fungi. M.: "Agropromizdat", 1990, p. 172-173.

20. V.I. Bilay, E.Z. Koval. Aspergillus: determinant. K.: "Naukova Dumka", 1988, 204 p.

21. G.L. Simbera. Large practicum on microbiology. M.: "Higher school", 1962, p. 106-112.

22. Methodical recommendations. Determination of fungicidal properties and optimal modes of disinfectant application on test cultures of the species $A s$ pergillus. Approved by the State Committee of Veterinary Medicine of Ukraine, prot. № 1, 2324.12.2009.

Article received 16.06.2021 


\section{ИССЛЕДОВАНИЕ ВЛИЯНИЯ ПЛАЗМОХИМИЧЕСКОЙ И ОЗОНОВОЙ ОБРАБОТКИ НА ИСКУССТВЕННО ВНОСИМУЮ МИКРОФЛОРУ В МОДЕЛЬНЫХ ВОДНЫХ РАСТВОРАХ}

\section{Г.В. Таран, Д.В. Кудин, А.А. Замуриев, П.О. Опалев, М.О. Ярошенко, О.М. Корнейков, В.Л. Арефьев,}

М.В. Калашник

Проведены пилотные исследования по определению биоцидного воздействия озона и плазмохимического разряда в течение 1,2 и 3 ч на вирус инфекционного ринотрахеита штамма «Молдавский», референтный штамм кишечной палочки Escherichia coli ATCC №25922, атипичные микобактерии вида Муcobacterium phlei и музейный штамм Aspergillus flavus, искусственно внесенные в воду. Показано, что обе обработки водного раствора, контаминированного вирусом инфекционного ринотрахеита, обнаружили вирулецидные свойства на $95 \ldots 100 \%$. Установлено, что бактерицидная (бактериостатическая) эффективность озонирования воды с кишечной палочкой составляла $100 \%$ для всех временных параметров, а для плазмохимического разряда бактериостатическое действие (на $23 \%$ ) проявилось при обработке в течение 3 ч. При этом бактерицидная (бактериостатическая) эффективность озонирования проб воды, контаминированных микобактериями вида M. phlei, составляла $65 \%$ только для экспозиции 3 ч. Обработка плазмохимическим разрядом не выявила бактериостатического эффекта при экспозиции. При изучении фунгицидных (фунгистатических) свойств озоновой обработки водного раствора, контаминированного тест-культурой Aspergillus flavus, yстановили фунгицидные свойства - обнаружили задержку роста на $95 . . .98 \%$. Плазмохимическая обработка не проявила ни фунгицидных, ни фунгистатических свойств.

\section{ДОСЛІДЖЕННЯ ВПЛИВУ ПЛАЗМОХІМІЧНОЇ ТА ОЗОНОВОЇ ОБРОБКИ НА ШТУЧНО ВНЕСЕНУ МІКРОФЛОРУ В МОДЕЛЬНИХ ВОДНИХ РОЗЧИНАХ}

\section{Г.В. Таран, Д.В. Кудін, О.О. Замурієв, П.О. Опалєв, М.О. Ярошенко, О.М. Корнєйков, В.Л. Арєф'єв, М.В. Калашнік}

Проведено пілотні дослідження щодо визначення біоцидного впливу озону та плазмохімічного розряду впродовж 1, 2, та 3 год на вірус інфекційного ринотрахеїту штаму «Молдавський», референтний штам кишкової палички Escherichia coli ATCC №25922, атипові мікобактерії виду Mycobacterium phlei та музейний штам Aspergillus flavus, які штучно внесені до води. Показано, що обидві обробки водного розчину, контамінованого вірусом інфекційного ринотрахеїту, виявили віруліцидні властивості на $95 \ldots 100 \%$. Встановлено, що бактерицидна (бактеріостатична) ефективність озонування рідини з кишковою паличкою становила $100 \%$ для всіх часових параметрів, а для плазмохімічного розряду бактеріостатична дія (на $23 \%$ ) проявилося при обробки впродовж 3 год. При цьому бактерицидна (бактеріостатична) ефективність озонування проб води, контамінованих мікобактеріями виду М. phlei, складала 65\% тільки за експозиції 3 год. Обробка плазмохімічним розрядом не виявила бактеріостатичного ефекту за жодної експозиції. При вивченні фунгіцидних (фунгістатичних) властивостей озонової обробки водного розчину, контамінованого тест-культурою Aspergillus flavus, встановили фунгіцидні властивості - виявили затримку росту на $95 \ldots 98 \%$. Плазмохімічний розряд не виявив ні фунгіцидних, ані фунгістатичних властивостей. 